\title{
A produção científica do J Vasc Bras
}

\author{
The scientific production of J Vasc Bras \\ Telmo P. Bonamigo*
}

Honrado com o compromisso de escrever um editocom todos os convidados que já tinham prestado servirial sobre o trabalho "A produção científica do J Vasc Bras: conquistas e desafios”, de Costa-Val \& Sousa Filho $^{1}$, devo inicialmente festejar o ato e cumprimentar os autores pela feliz e oportuna iniciativa.

Uma sociedade científica só é grande quando estabelece laços sóliços à nossa Sociedade. Para ampliar nossa força de ação, providenciamos, já desde o primeiro volume, a tradução para o inglês de todos os textos

Veja artigo relacionado na página 6

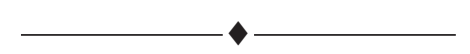

dos, científicos, corporativos e afetivos com todos os seus associados. Nossa Sociedade, ao longo dos anos, vem percorrendo esta grande caminhada, desde a Sociedade de Angiologia, passando, mais recentemente, para a SBACV.

Uma associação científica só é grande quando, além de um elevado número de competentes e qualificados associados, tem uma via de comunicação científica adequada para promover a necessária e oportuna difusão do conhecimento atualizado aos seus associados.

No contexto editorial, nossa Sociedade percorreu vários caminhos, até atingir os dias de hoje. Duas outras publicações existiram, porém com a característica de serem privadas, a serviço da Sociedade. Houve então um momento de crise maior, e como esta pode ser uma fonte de solução quando bem conduzida, planejou-se a criação de uma nova revista, o J Vasc Br, agora J Vasc Bras.

Assim, pela primeira vez, nossa Sociedade passou a ter uma revista própria, com seu "ônus e bônus". Nossa preocupação imediata foi somar a força de todos, reconhecer o trabalho dos que nos antecederam e pensar alto. No Conselho Internacional, tivemos a alegria de contar editorial não seria apenas um a mais, porém o definitivo para nossa Sociedade.

Com o compromisso da pontualidade, recuperou-se a indexação do LILACS e conseguiu-se a indexação SciELO. A seguir, constatou-se um crescimento no número de trabalhos publicados. Hoje temos, no trabalho de Costa-Val e Sousa Filho, uma excelente contribuição, que divulga uma análise de tudo o que foi publicado pelo J Vasc Br/J Vasc Bras até agora.

Gostaria de fazer algumas considerações sobre alguns pontos destacados pelos autores, com a tomada de posição pessoal. O percentual de $37,8 \%$ de artigos originais constitui-se em um desafio a ser vencido pelos associados da SBACV principalmente, e não pelos editores do J Vasc Bras. Só um esforço conjugado irá aumentar de forma significativa o número mínimo (64) de trabalhos originais publicados ao ano. Como, para cada problema, há de haver uma solução, se 20 programas de residência enviassem dois trabalhos originais por ano, e mais 40 associados independentes mandassem um trabalho por ano, o problema estaria resolvido.

* Professor adjunto, Cirurgia Vascular, Fundação Faculdade Federal de Ciências Médicas de Porto Alegre (FFFCMPA), Porto Alegre, RS. Chefe, Serviço de Cirurgia Vascular, Santa Casa de Porto Alegre, Porto Alegre, RS. 
Outro assunto que merece ser discutido é o número de citações nacionais feitas pelos autores nacionais. $\mathrm{O}$ pequeno percentual pode ser atribuído, em princípio, à pobre tradição que temos de publicar. Infelizmente, por causas nem sempre defensáveis, o pouco que é publicado com méritos para ser citado raramente o é. Este fato é devido a uma questão cultural e mercadológica. Nos Estados Unidos, "todos citam todos" os autores de lá. Mas é bom lembrar que só ocasionalmente esses autores decidem transpor o Atlântico. Já a maioria absoluta dos nossos autores nacionais "adora" o hemisfério norte.

Aqui temos um contexto cultural: somos mais latinos que anglo-saxões. Já publiquei duas colunas procurando alertar sobre a importância da citação do autor nacional pelo autor nacional. Tenho certeza de que o tempo e a força dos autores mais jovens haverá de, aos poucos, vencer essa omissão não justificável. Esse assunto será resolvido quando muitos dos autores nacionais, respeitosamente, "despirem-se um pouco do seu egoísmo" e enxergarem, em outro autor nacional, não um concorrente, mas um parceiro e caminhante, ambos indo na mesma direção.

Os autores colocam, ainda, outra questão. Não se justifica que muitas teses aprovadas, até com distinção, não sejam publicadas por falta de interesse do autor ou por falta de cobrança do seu orientador. Esse assunto começa a ser resolvido na medida em que o orientador só libera a defesa da tese se o candidato obtiver aprovação de publicação em revista.
Os autores finalizam seu excelente trabalho lembrando que, se a necessidade e a tradição de publicar, para o professor ou mesmo o médico assistencialista, não é forte aqui, isso se deve, em parte, ao compromisso do americano manifestado pelo "publish or perish", inexistente no Brasil. Discordo dos autores quando colocam que, para o autor acadêmico brasileiro, é fundamental publicar no estrangeiro, "sendo até tolice exigir que o façam aqui”. Isso pode ser real nas ciências básicas, na linha da pesquisa pura. Mas, para a maioria dos professores com atividade assistencial e carreira acadêmica consolidada, pouca diferença faz ter dois ou mais trabalhos publicados no exterior. Se esses trabalhos fossem publicados aqui, rapidamente teríamos um crescimento significativo do processo editorial brasileiro.

Concluindo, saúdo a ótima notícia que é a futura disponibilização, pela SBACV, de assessoria técnica para os autores com material adequado porém sem prática maior na publicação, a fim de terem o suporte necessário.

Finalizo cumprimentando os autores pela bela contribuição e, na condição de primeiro Editor do J Vasc Bras, manifesto minha alegria ao constatar o seu crescimento, e recomendo a cada um dos associados que somem esforços em nome desta causa.

\section{Referência}

1. Costa-Val R, Sousa Filho JC. A produção científica do J Vasc Bras: conquistas e desafios. J Vasc Bras. 2008;7:6-16. 